\title{
The Hebrew Bible in CONTEMPORARY PHILOSOPHy OF RELIGION
}

Author:

Jacobus W. Gericke

\section{Affiliation:}

${ }^{1}$ School of Basic Sciences, Faculty of Humanities, North-West University, Vaal Triangle Campus, South Africa

\section{Correspondence to: Jacobus Gericke}

email:

21609268@nwu.ac.za

Postal address:

22 Drommedaris, Toon

van der Heever Street,

Sasolburg 1947, South

Africa

\section{Keywords:}

Hebrew Bible; philosophy of religion; analytic traditions; continental traditions; historical overview

\section{Dates:}

Received: 13 May 2010

Accepted: 23 Sept. 2010

Published: 19 Nov. 2010

How to cite this article: Gericke, J.W., 2010,

'The Hebrew Bible in contemporary philosophy of religion', Verbum et Ecclesia 31(1), Art. \#395, 6 pages. DOI: 10.4102/ ve.v31i1.395

\section{This article is available} at: http://www.ve.org.za

(C) 2010. The Authors. Licensee: OpenJournals Publishing. This work is licensed under the Creative Commons Attribution License.

\begin{abstract}
Some dialogue among these specialists, especially between biblical scholars and philosophers of religion, is unquestionably long overdue.
\end{abstract}

(Stump 1985:1)

Over the last few decades, there has been an increased concern for the establishment of more sustained interdisciplinary dialogue between biblical scholars and philosophers of religion. In this article, aimed at biblical scholars, the author as biblical scholar offers a descriptive and historical overview of some samples of recourse to the Hebrew Bible in philosophical approaches in the study of religion. The aim is to provide a brief glimpse of how some representative philosophers from both the analytic and continental sides of the methodological divide have related to the biblical traditions in the quest for a contemporary relevant Christian philosophy of religion.

\section{INTRODUCTION}

Biblical scholars seldom take an interest in philosophy of religion. There is currently no research in biblical scholarship exclusively concerned with the reception history of the Hebrew Bible in contemporary Christian philosophy of religion. In this paper, the research problem pertains to finding examples of how representative philosophers of religion have tended to involve the biblical materials in their philosophical undertakings. The question regarding philosophers' recourse to the Hebrew Bible will be answered, not from the perspective of philosophy of religion, but from the perspective of a biblical scholar, whose primary objective in this article is to provide a historical and descriptive type of introductory overview on the topic. In addition, the implied audience is scholars of the Hebrew Bible, even though other readers might find the overview useful or informative.

As regards the outline and format of discussion, the concern lies with identifying instances where philosophers of religion have had explicit recourse to motifs from the Hebrew Bible in a representative manner, which means that unfortunately not everybody who has had something of relevance to say can be mentioned. It is also beyond of the scope of the discussion to offer an in-depth critical evaluation of the cited samples, a practical necessity which does not deter from the actuality of the brief glimpses provided. Viewed chronologically, there is always a need for a descriptive overview, the value of which lies in being informative. By offering examples of recourse to the Hebrew Bible from both the pluralist analytic and continental sides of the methodological divide in philosophy of religion, this study aims at creating a greater awareness, via a most basic and cursory introduction, of the state of interdisciplinary relations on ground level.

\section{THE HEBREW BIBLE IN ANALYTIC PHILOSOPHY OF RELIGION}

Over the last few decades, reluctance to involve the Hebrew Bible in philosophy of religion has partly diminished in analytic (usually 'Anglo-Saxon') circles. As will become clear in the discussion to follow, some philosophers of religion still retain a definite interest in particular and specific aspects found within ancient Israelite religious traditions. We shall see how a few are actually calling for closer interaction between philosophers of religion and biblical scholars. A good example of this comes from a remark by Eleanor Stump (1985) in an article entitled Modern biblical scholarship, philosophy of religion and traditional Christianity:

Partly because it requires a set of highly specialized skills, the research generated by this historical approach has not received much critical scrutiny either from professional historians or from philosophers, even those with a professional interest in the study of religion. And some dialogue among these specialists, especially between biblical scholars and philosophers of religion, is unquestionably long overdue. No doubt philosophers of religion can benefit greatly from biblical scholars by learning about the historical foundations of Christianity and Judaism. Surely some detailed acquaintance with biblical criticism is crucial for understanding the religion one is attacking or defending, and the philosophical examination of Judaism and Christianity will not be done well without some attention to the best contemporary understanding of the biblical texts on which those religions are founded.

(Stump 1985:1)

As it stands, there is nothing obviously problematic about these remarks. However, in the context of the particular article a clearly fundamentalist agenda is operative behind the scenes. In the rest of the discussion, the author rages against biblical criticism and the 'unorthodox' findings of historical critical research. Stump (1985) qualifies the need to learn from biblical scholars with the insinuation that they themselves should first take cognisance of what philosophers of religion are doing, which in turn will allegedly render historical-critical research defunct:

On the other hand, however, the final judgment regarding historical authenticity may turn out very differently if biblical scholarship is subjected to analysis and questioning by philosophers. Many cannot survive philosophical scrutiny, and bringing philosophical analysis to bear on biblical criticism often alters the historical conclusions which can be justified by that discipline.

(Stump 1985:1) 
Yet this is not an isolated instance and other prominent analytic Christian philosophers of religion, for all their philosophical sophistication, still cling to fundamentalist hermeneutical assumptions. To be sure, these philosophers might wish to justify their conservatism by appealing to the implications of the development of post-foundationalism and anti-evidentialism in the epistemology of religion. But this is a diversion and the philosophical superstructure of complex philosophical arguments tends to be a smokescreen for the weakness of the biblical-theological base structure. This is particularly evident in the writings of someone like Alvin Plantinga who, on the one hand, is perfectly capable of talking the talk of sophisticated philosophy. On the other hand, however, when venturing across disciplinary lines in his When faith and reason clash: Evolution and the Bible (1991) and Two (or more) kinds of Scripture scholarship, Plantinga's (2000) rhetoric is typical of fundamentalist discourse, bracketing two centuries of biblical criticism:

Scripture is inerrant: the Lord makes no mistakes; what He proposes for our belief is what we ought to believe. Scripture is a wholly authoritative and trustworthy guide to faith and morals. God is not required to make a case. The principal Author of the Bible - the entire Bible - is God himself, not so much a library of independent books as itself a book with many subdivisions but a central theme: the message of the gospel ... 'interpret Scripture with Scripture.' One can't always determine the meaning of a given passage just by discovering what the human author intended.

(Plantinga 2000:385)

These are supposed to be the profound thoughts by a philosopher of religion many consider the best of his generation; and yet there is nothing in the way of critical historical consciousness (one is reminded of Greek philosophers interpreting Homer with Homer) or any understanding of what critical biblical scholarship is actually all about (see Plantinga 1990). As a result, all of Plantinga's philosophical concerns with the Hebrew Bible are susceptible to the critique James Barr presented when he discussed the 'philosophical roots' and philosophical naïveté of lay-fundamentalists in Fundamentalism (Barr 1977:270-277). In this regard, Barr (2000:28) himself noted the interest of philosophers of religion in biblical studies and some of the hermeneutical oddities therein, in the publication Hermes and Athena: Biblical exegesis and philosophical theology. This work was intended as a pioneering venture in dialogue between the fields of contemporary philosophy of religion and biblical studies but focuses mostly on the New Testament (Christology, resurrection, miracles, moral development, authority and the nature of historical-critical inquiry). A philosophical analysis aimed at the conceptual clarification of ancient Israelite religion for its own sake is for all practical purposes not pursued.

Whatever the concern with the New Testament involves hermeneutically, a closer look into the way some analytic Christian philosophers of religion work with the biblical texts makes one wonder what would happen if they really took the findings of biblical criticism more seriously. Fundamentalism as such has been of interest in philosophy, as in the case of the Oxford philosopher of religion, Harriet Harris (see Harris 2008). But perhaps the best critical assessment of fundamentalism in philosophy of religion was offered by Levine (2000) who pointed out that:

Contemporary philosophy of religion now is, and for the past 30 years has been, dominated by the religious agendas of Christian conservatives. Far from 'now becoming recognized once again as a mainstream philosophical discipline' - as a catalogue blurb (Philosophy 2000) announcing a new Ashgate Series in the philosophy of religion falsely proclaims - not only has mainstream philosophy long ignored such philosophy of religion, but so has the study of religion generally (e.g. biblical scholarship, theology and religious studies).

(Levine 2000:89)

Examples of fundamentalist philosophers of religion include Alvin Plantinga, Norman Geisler, William Lain Craig, Peter van Imwagen, Nicholas Wolterstorff, Stephen T. Davis, Eleanore
Stump, John Frame, Richard Swinburne and many others. Their beliefs regarding referentiality in the text-reality relation are often of the naive-realist varieties, notwithstanding individual idiosyncrasies and degrees of dogmatism. In the end, for all their jargon and philosophical sophistication, these scholars' popular variety of philosophical theology's biblical hermeneutics is ultimately little more than 'fundamentalism on stilts' (see Gericke 2009:5).

Of course, fundamentalist Christian philosophers have their supposed epistemological justification to show that even when belief cannot be proven true, it is at least not totally irrational. And of course, they will dispute that the idea of God may not be properly basic. But the real problem with this kind of philosophy of religion is that it brackets the history of religion. Conservative philosophers show a general lack of appreciation of the major problems that 20th century Old Testament theology had to grapple with: theological pluralism, the problem of history, the anachronism of classical philosophical-theological categories, mythological parallels and comparative religion, the question of a Mitte, evaluative as opposed to descriptive readings and so on. Many fundamentalist Christian philosophers might think they know what biblical criticism involves but their polemic engages only conservative caricatures and straw men. Interested only in debunking unorthodox conclusions, no attempt is made to obtain a real grasp of the research that led to these conclusions in the first place. Such philosophy of religion holds no answers for biblical scholarship as it does not understand the questions.

If this judgment sounds harsh, consider the realities. A recent conference at the University of Nortre Dame on 12 September 2009 had the theme: 'My ways are not your ways: the character of the God of the Hebrew Bible'. Unfortunately, as can be expected at Nortre Dame, where Plantinga and company hail from, the participants seem once again to have mistaken philosophy of religion for conservative Christian apologetics. More of the same is evident in remarks related to the Hebrew Bible in the recent Oxford handbook of philosophy of religion (especially Evans 2005:223-243), The Oxford handbook of philosophical theology (especially Davis 2009:30-53) and Oxford readings in philosophical theology: Volume 2. A number of contributions to these publications will convince any non-fundamentalist biblical scholar that the philosophical intricacies are rendered void by an utter lack of appreciation of the philosophical implications of problems wrestled with in 20th century biblical theology.

Fundamentalism is also present in the process philosophy of some neo-Thomists and Evangelical Christian philosophers calling themselves 'open theists'. The latter is a quasifundamentalist offshoot of process philosophy of religion and its interest for us lies in the fact that it too is philosophy concerned with the Hebrew Bible. Open theism itself has been a significant topic in conservative philosophy of religion, as for example in the writings of Clark Pinnock, Richard Rice, John Sanders, William Hasker and David Basinger. Other philosophers of religion such as A.N. Prior, J.R. Lucas, Peter Geach, Richard Swinburne and Richard Purtill had also advocated open theism in their writings prior to this date, though not under that name (see Rissler 2010).

In process philosophy of religion, the Hebrew Bible is once again read without adequate attention to theological pluralism and heterodoxy and features mainly as a source for dicta probanta. So whilst the philosophers are willing to admit the presence of texts that contradict classical theist orthodoxy, their philosophical readings of the Hebrew Bible are simply the other side of Calvinist fundamentalism in that they seek to harmonise everything in the opposite direction. In addition, whilst they accept the fact that texts assume cognitive limitations on the part of $\mathrm{YHWH}$, process philosophy of religion in the form of open theism seems blissfully ignorant of the 'dark side' of the deity in relation to the actualisation of evil and the frequent overriding of human free will. 


\section{THE HEBREW BIBLE IN CONTINENTAL APPROACHES}

A different sort of interest in the Hebrew Bible is found in the work of continental philosophers of religion (usually French and German, but also with representatives from Englishspeaking countries). There has been some tension between these philosophers and theologians and some of the fundamentalist Christian philosophers discussed above. Between 1989 and 1995 a debate took place in the journal Faith and Philosophy, initiated by the liberal theologian Gordon Kaufman. The topic for discussion concerned the question of whether theologians should take any notice of, or show any interest in, the work of philosophers of religion such as Plantinga, Wolterstorff and Swinburne. Kaufmann suggested that the latter philosophers simply presuppose traditional theistic conceptions and formulations and lack sensitivity to the significance of religious pluralism, to the symbolic and culturally relative nature of all talk about the mystery of Deity (see Hebblethwaite 2005:3).

Whatever we make of this critique, continental philosophy of religion does seem to exhibit more historical consciousness than many analytic approaches. Yet the biblical scholar will note that this is often coupled with curious generalisations about conceptions of YHWH in the texts. There seems to be operative an over-optimistic selectiveness in what counts as relevant godtalk and a repression of unbelief in the wake of the collapse of realism in biblical theology.

On the one hand, continental philosophers seem to know that there are serious differences between the stereotypical God of the philosophers and the God of Abraham, Isaac and Jacob and that YHWH does not fit into the perfect-being theology of classical theism, something which analytic philosophers of religion often seem to forget (or do not wish to know). John Caputo (as cited in Trakakis 2007) once wrote:

That very finite Hellenistic creature called 'God' is a being cut to fit the narrow needs of Greek ontology, of Parmenides and Plato, who were scandalized by time and motion and change, and of Aristotle, who did the best he could to make the name of matter and motion respectable among the Greeks. But from a biblical point of view, this highly Hellenic theos was an imperfect - may I say a pathetic, or better an apathetic? - way to think of God. It had nothing to do with Yahweh who was easily moved to anger and jealousy, who was a God of tears and compassion, who suffered with his suffering people, who was moved by their sighs and lamentations, who was angered by their meanness of mind and had a well-known and much respected temper, who had, in short, a short fuse.

(Trakakis 2007:38)

Trakakis (2007:1-47) also shows stylistic differences in the language of the two traditions, taking the work of Alvin Plantinga and John D. Caputo as exemplars of the analytic and continental schools respectively. He goes on to show how each philosophical school models itself on different theoretical practices, the analytic school mimicking the scientific style of inquiry, whilst in continental philosophy it is the arts and humanities rather than the sciences that provide the model for philosophical discourse. By situating themselves in such different genres, analytic and continental philosophers have developed contrasting, if not mutually exclusive, methods for pursuing the philosophy of religion. Often being liberal systematic theologians, many continental philosophers of religion tend to work rather reconstructively and in the end like to think of God as love and thus take leave of the dystheistic elements in the conceptions of God in the Hebrew Bible.

A good example here, with which Hebrew Bible scholars will be very familiar, is Paul Ricoeur as a philosopher of religion. To be sure, philosophy of religion was not Ricoeur's only interest and therein he did not limit himself to the Hebrew Bible. However, Ricoeur's work has been utilised in research on the Hebrew Bible but then with regard to his hermeneutics, narrative theory, the role of the imagination, the prevalence of metaphor and the second naiveté, rather than with reference to his phenomenological-type philosophy of religion with which he has read a number of biblical texts. Still, Ricoeur has written on Hebrew Bible in many of his writings and a very good example of this before his death in 2005 is the 1997 publication co-edited with André LaCocque entitled, Thinking biblically: Exegetical and hermeneutical studies (LaCocque \& Ricoeur 2003).

In this publication, Ricoeur is in dialogue with a biblical scholar. They focus on six texts from the Hebrew Bible, trying to show these to consist of vibrant, philosophically consequential and unceasingly absorbing discourse. They know very well that philosophy brings concepts, arguments and theories that were forged outside the biblical field of thought. Yet this does not stop them from philosophical readings and the volume takes the form of parallel essays on what they call 'strong texts': Genesis 2-3, Psalm 22 ('My God, my God, why have you forsaken me?'), the Song of Songs, Exodus 3:14 ('God said to Moses, "I am who I am"'), the Joseph story in Genesis 44 and others. In his philosophical exegesis Ricoeur assumes that the subsequent history of the biblical text within Jewish and Christian traditions should be a factor in its interpretation. Because Ricoeur's agenda is ultimately Christian, canonical (i.e. pan-biblical also involving the New Testament) and normative, he uses revamped bits and pieces from the Hebrew Bible for contemporary philosophy of religion rather than using philosophy of religion for a historical clarification of ancient Israelite religion (see also Pallesen 2008:44-62; Vanhoozer 1990).

A second continental philosopher whose work has some bearing on the interpretation of the Hebrew Bible is Emmanuel Levinas (see Long 2003:447). Some circles in biblical scholarship have turned eagerly to Levinas, as to Ricoeur, for new ways to look at the Hebrew Bible, which is not surprising, given how one finds an unlikely match between philosophy and ancient Israelite religion in his work (see Ezkenazi, Phillips \& Jobling 2003). Yet he too was no philosopher of religion only and the tension between the Hebrew Bible and western philosophy has led to a distinction between Levinas' writings on philosophy and Judaism respectively. Still, one cannot read much of his work without encountering direct and indirect allusions to the biblical material.

Writing as a philosopher, Levinas rejects Pascal's distinction between the God of Abraham, Isaac and Jacob and the God of the Philosophers. According to Levinas, philosophical discourse should be able to include YHWH of whom the Hebrew Bible speaks. He argues that what biblical theologians refer to as Greek as opposed to Hebrew mentality is recommended by the biblical texts themselves (see Katz \& Trout, 2005:121-152). He believes somewhat anachronistically that the god of Israel was assumed to be transcendent and beyond the language and thinking of being. Levinas also seems more interested in reinterpreting the traditions for the sake of constructing a contemporary philosophical perspective than in using philosophy for a better historical understanding of the Hebrew Bible from a purely descriptive perspective. His concern is therefore not limited to the Hebrew Bible for its own sake but like other Jewish philosophers he seeks to go beyond it to include Talmudic and later Jewish philosophical traditions.

Our next example of a philosopher of religion in the continental tradition with connections to the Hebrew Bible is Jean-Luc Marion. In God without being, Marion challenges the tradition of metaphysical theology and claims that God must no longer be thought of in terms of the traditional category 'Being'. As Long (2003:446) notes, Marion introduced the concepts of the idol and the icon - two modes of apprehending the divine in reality. The distinction is highly reminiscent of Barth's distinction between reason and revelation. According to Marion, the idol and icon belong to two distinct and competing historical movements. The idol is negative and Greek (philosophical) whilst the icon 
is positive and Hebraic (biblical). Marion thus invoked the old Hebrew-Greek distinction, but then somewhat differently from Levinas and more in the current of the older, illusionary, binary opposition between Hebrew and Greek thinking which privileges the Hebraic. In short, like Levinas before him, Marion was not so much interested in a philosophical clarification of ancient Israelite religion as in the use of motifs derived there from on the way to a more normative and constructive contemporary philosophy of religion (see Long 2003:447-450; Marion 1991:16).

Next to be mentioned is the Cambridge philosopher of religion Don Cupitt. Though not so much concerned with ancient Israelite religion for its own sake, in several contexts Cupitt reads the Hebrew Bible in a very creative manner for the sake of producing a contemporary philosophy of religion. In doing so, he often combines philosophical and historical modes of interpretation. In Sea of faith for example, Cupitt (1984:61-64) provides a brief philosophical summary of the Hebrew Bible's worldview. In After God: The future of religion, Cupitt (1997) combines the history of Israelite religion with philosophy of religion in remarks like the following:

As we see in the Hebrew Bible ... the dispute with God becomes the classic arena in which selfhood is elaborated and human subjectivity is produced. Nowhere else do we find such psychological riches. The psalmist moves from ecstatic adoration to bitter reproach to penitent submission and then to joy and gratitude. Prayer was the classic method of investigating and exercising the self, opening speculative thought and stretching the soul, and the relationship to God thus developed became a resource utilized in the construction of many other human relationships ....

(Cupitt 1997:32)

Cupitt (1997) is one of the few philosophers of religion who actually takes cognisance of the theological pluralism and diachronic diversity in ancient Israelite religion, as represented in the biblical traditions:

And Nietzsche was right to describe the Hebrew Bible as the best book in the world, because it is the book of the one religion that above all others is not just a system of worship but something far greater - an argument with itself.

(Cupitt 1997:42-43)

What is most refreshing is Cupitt's refusal to panel-beat the God of the Bible to conform to the perfect-being theology of analytic Christian philosophy of religion. At one point Cupitt (1997) poignantly remarks on Harold Bloom's view on the nature of YHWH in a way that shows one can describe the text in philosophical terms without bracketing the history of religion or explaining away conceptual heterodoxy:

This God, the Yahweh of the J writer in the Hebrew Bible, is...like a powerful uncanny male child, a sublime mischief maker, impish and difficult. He resembles Lear and the Freudian superego in being a demonic and persecuting father; entirely lacking in self-knowledge and unwilling to ever learn anything. Like the human characters he interacts with, he has a continually changing consciousness. He manifests the pure energy and force of becoming. He is Nietzschian will-to-power, abrupt and uncontrollable, subject to nothing and nobody.

(Cupitt 1997:36)

Aside from this, Cupitt frequently remarks on this or that interesting aspect in the text from a philosophical perspective, even though it is never his exclusive concern but merely part of his argument concerning something else. One thinks of his discernment of non-realist tendencies in ancient Israelite tradition history (see Cupitt 1980:45). In one discussion, Cupitt (2003) writes as follows regarding the philosophical implications of biblical criticism for how we think of ancient Israelite god-talk in the biblical text:

The Old Testament can now be seen as profoundly voluntaristic and expressive in its use of religious language.

(Cupitt 2003:247)
Cupitt has also written on fictionalism in biblical narrative art, the folk-philosophy of language implicit in Genesis 1-3, traces of Greek metaphysical assumptions, the concept of generic divinity, on the politics of wisdom literature, the folk-psychology of the psalms and more (see Cupitt 1991, 2009). In his later writings, Cupitt came to rely much on the biblical scholar Thomas L. Thompson's fictionalist approach and in the end is interested in providing a post-modern theory of religion in general, in which reflections on ancient Israelite religion feature relatively marginally.

Another figure is Keith Ward, who comfortably straddles the analytic/continental divide with his phenomenological, historical and comparative approach to philosophy of religion. Ward has written a number of philosophical discussions of aspects of ancient Israelite religion and his reflections on Judaism vis-à-vis other faiths include descriptive philosophical treatments of the Hebrew Bible's concepts of 'revelation', 'creation', 'human nature' and 'God' (see Ward 1994:111-133, 1996:3-36; 1998a:159-185; 1998b:81-98 and 1998b:81-82). These reflections have recognised the gap in research when it comes to a philosophical perspective on ancient Israelite religion for its own sake:

There is need for a philosophical account of the nature of this God, which might clarify the way in which other peoples might relate to him, or come to understand what he is. There is no such account in the Bible itself, which confines itself to revelations given to the patriarchs and prophets of Israel. Both the Upanishads and the Buddhist Pali Canon contain sections which may fairly be regarded as philosophical or doctrinal, exploring views of the nature of ultimate reality in a reflective and meditative way. In the Old Testament there are virtually no passages of that sort. Philosophical reflection on the nature of Jahweh [sic], the god of Abraham, Isaac and Jacob is almost entirely absent (emphasis mine). It is accordingly very difficult to know what the Hebrews thought about God; that is, how they themselves interpreted the words they used about God. I rather suspect they thought as many different things about God as different philosophers do. But we do have enough material to construct a fairly clear idea of the Biblical God, though its interpretation cannot be decisively established.

(Ward 1994:111-133)

Note that the absence of a philosophical account of YHWH in the biblical texts, far from being seen as providing any sort of rationale for avoiding philosophical reflection, is in fact implied to be precisely the reason why it is so sorely needed. Working with phenomenological and comparative concerns, Ward's writings are more historically conscious than those of other analytic philosophers of religion. Yet even for Ward, whose writings at times come very near to a descriptive philosophical reading of biblical texts, the Hebrew Bible is not his sole concern and he remains a Christian philosopher of religion. Anyone looking for a better example of how the Hebrew Bible could be read in philosophy of religion for constructive purposes will find it in Ward's descriptive reflections. He does so with a sense of humour, self-critical acumen and creativity that make his work easy to follow and always a pleasure to read, even when one disagrees with him.

Our next example from the continental side comes from the work of Merold Westphal who specialises in post-Kantian philosophy and often concerns himself with issues at home in the philosophy of religion. In his discussion of philosophers like Kant and Kierkergaard, Westphal has not hesitated to comment in philosophical terms on contemporary relevant elements in Israelite religion as represented in the Hebrew Bible (Westhphal 1984; 1987). His approach to the text commonly adopts a phenomenological perspective in the form of a descriptive type of philosophy of religion. Like the other philosophers of religion discussed, Westphal's concern with ancient Israelite religion is still relatively marginal and never purely descriptive or historical in orientation. Yet his work also suggests that the Hebrew Bible and its contents can be philosophically interesting and that if 
one does it right there can be no hermeneutical objections to a philosophical account of its beliefs and practices.

Finally there is Gillez Deleuze who, along with Felix Gauttari in both Anti-Oedipus (2004a) and A thousand plateaus (2004b), refers to and remarks on the Hebrew Bible. In the former there is a reference to Abraham sacrificing his son (see Deleuze \& Gauttari 2004a:302). In the later work there is a more extensive commentary including the following on the phenomenon of ancient Israelite prophecy:

When a prophet declines the burden God entrusts to him (Moses, Jeremiah, Isaiah, etc.) it is not because the burden would have been too heavy as with an imperial oracle or seer who refuses a dangerous mission. It is instead a case like Jonah's who by hiding and fleeing and betraying anticipates the will of God more effectively than if he had obeyed. The prophet is always being forced by God, literally violated by him, much more than inspired by him. The prophet is not a priest. The prophet does not know how to talk. God puts words in his mouth: word-ingestion, a new form of semiophagy. Unlike the seer, the prophet interprets nothing: his delusion is active rather than ideational or imaginative. His relation to God is passional and authoritative rather than despotic or signifying; he anticipates and detects the powers (puissances) of the future rather than applying past and present powers (pouvoirs).

(Deleuze \& Gauttari 2004:137)

There are many such scattered remarks that couch the phenomenon of prophecy in the language of post-modern psycho-analytical jargon, thus offering a philosophical clarification of the phenomenon as understood against the backdrop of other contemporary interests. The same goes for other post-modern philosophers of religion such as Taylor (1987:55-56; 2007:167-168, though here the interest lies more with reception history).

In addition to the individual philosophers mentioned above, a specific variety of the continental habit is also evident in some German introductions to philosophy of religion that also include a historical precursor to the philosophical discussion proper. These usually feature a section that shows the ancient Near Eastern background to philosophical thought about religion. One example is Hermann Deuser's Religionsphilosophie which contains a chapter entitled, Biblische, antike und scholastische Tradition (see Deuser 2008:56-62; 75-82). As is common in this kind of historical background, the concern is not so much a philosophical account of ancient Israelite religion as a historical discussion of how it represents a turn away from myth, a philosophy of history and how ideas of monotheism and critical wisdom prefigure some later Greek philosophical ideas. In this publication for example, Deuteronomistic and Joban theology are touched on and compared with related ideas elsewhere (e.g. Job with Socratic dialogue). The author, rather than offering a philosophical description, is satisfied with repeating the ideas of biblical scholars (von Rad, Otto Kaiser). No more than a dozen pages in total is devoted to the biblical context before moving on to more interesting material from western philosophy.

Finally, over the last decade attempts at interdisciplinary engagement can also be seen in the coming into being of the Journal of Philosophy and Scripture, an online electronic journal edited by Graduate Students in Philosophy at Villanova University. The editorial advisor, James Wetzel, offers the following online mission statement:

The Journal of Philosophy \& Scripture is an e-journal dedicated to reading scripture in light of philosophy and to examining philosophy in light of scripture. The Journal's task is informed by three primary aims: (1) to encourage philosophical discussions of religion to attend to the primary sacred texts (e.g. the Bible, the Qur'an, the Bhagavad-Gita) that fundamentally shape the religions under discussion, (2) to encourage a process of mutual reflection by means of which both philosophy and scripture may be more clearly illuminated, and (3) to do the above with a keen eye to possible effects on the ways in which we practice philosophy and religion.

(http://www.philosophyandscripture.org/index.html)
Although the journal is not exclusively devoted to the Hebrew Bible and Israelite religion, this too is an example of the ways in which philosophers have shown a concern for establishing links for the purpose of interdisciplinary research.

\section{CONCLUSION}

In this article, it has been shown that Christian philosophers of religion do at times engage withthe Hebrew Bible. No generalisation is possible since the role the texts play in the writings of both analytic and continental philosophers varies, irrespective of the ideological concerns of the reader in question. As we saw, many representative philosophers of religion have at times made hermeneutical or exegetical comments on the text or have looked to biblical motifs to elucidate a philosophical problem. Overall, in relatively recent times many big names on the analytic side of the divide have exhibited marked traces of fundamentalist hermeneutics (Plantinga, Craig, Swinburne, et al.). On the other side continental traditions have tended to be strangely selective, if not interestingly over-optimistic, when involving the biblical material at all (Caputo, Ricoeur, Levinas, etc). In most cases the interest lies with reinterpreting ideas in the Hebrew Bible to contribute to a discussion in contemporary philosophy of religion rather than using contemporary philosophy of religion descriptively to clarify the concepts, beliefs and practices of ancient Israelite religion. In some cases, interesting perspectives on the text were provided with which biblical scholars themselves might need to engage (Ward, Cupitt, Ricoeur, Westphal, Deleuze \& Gauttari, etc). Whatever one may think of this mixed state of affairs, at the very least Hebrew Bible scholars interested in working towards more extensive interdisciplinary relations with philosophy of religion should take cognisance of what philosophers proper have done with and to the text.

\section{REFERENCES}

Barr, J., 1977, Fundamentalism, SCM Press, London.

Barr, J., 2000, History and ideology in the Old Testament, Oxford University Press, Oxford.

Cupitt, D., 1980, Taking leave of God, SCM Press, London.

Cupitt, D., 1984, Sea of faith, SCM Press, London.

Cupitt, D., 1991, What's a story? SCM Press, London.

Cupitt, D., 1997, After God: The future of religion, Basic Books, London.

Cupitt, D., 2003, Sea of faith, 3rd edn., SCM Press, London.

Cupitt, D., 2009, Jesus and philosophy, SCM Press, London.

Davis, S.T., 2008, 'Revelation and inspiration', in T.P. Flint \& M. Rea (eds.), The Oxford handbook of philosophical theology, pp. 323-343, Oxford University Press, Oxford.

Deleuze, G. \& Gauttari, F., 2004a, Anti-Oedipus. Capitalism and schizophrenia, Continuum International Publishing Group, London.

Deleuze, G. \& Gautarri, F., 2004b, A thousand plateaus. Capitalism and schizophrenia, Continuum International Publishing Group, London.

Deuser, H., 2008, Religionsphilosophie, Walter de Gruyter, Berlin.

Evans, C.S., 2005, 'Faith and revelation', in W. Wainright, The Oxford handbook of philosophy of religion, pp. 323-343, Oxford University Press, Oxford.

Ezkenazi, T.K., Phillips, G.A., Jobling, D., (eds.), 2003, Levinas and biblical studies, Volume 43 of Semeia Studies, Brill, Leiden.

Gericke, J.W., 2009, 'Fundamentalism on stilts: A response to Alvin Plantinga's reformed epistemology', Verbum et Ecclesia, vol. 30, no. 2, Art. \#90

Harris, H., 2008, Fundamentalism and evangelicals, Oxford University Press, Oxford.

Hebblethwaite, B., 2005, Philosophical theology and Christian doctrine, Blackwell's, Oxford.

Katz, C.E. \& Trout, L., 2005, Emmanuel Levinas and the question of religion, pp. 121-152, Routledge, Taylor \& Francis, London/ New York. 
LaCocque, A. \& Ricoeur, P., 2003, Thinking biblically: Exegetical and hermeneutical studies, Chicago, University of Chicago Press, Chicago.

Levine, M.P., 2000, 'Contemporary Christian analytic philosophy of religion: Biblical fundamentalism, terrible solutions to a horrible problem, and hearing God', International Journal for Philosophy of Religion 48, 89-119.

Long, E.T., 2003, Twentieth century philosophy of religion, Kluwer Academic Publishers, Dordrecht/Boston/London.

Marion, J.L., 1991, God without being, University of Chicago Press, Chicago.

Pallesen, C., 2008, 'Philosophy of Reflection and Biblical Revelation in Paul Ricoeur', in Studia Theologica - Nordic Journal of Theology 62/1, 44-62.

Plantinga, A., 1990, 'Advice to Christian philosophers', in M.D. Beaty (ed.), Christian theism and the problems of philosophy, University of Notre Dame Press, Notre Dame.

Plantinga, A., 2000, Warranted Christian belief, Oxford University Press, New York.

Rea, M.C. (ed.), 2009. Oxford readings in philosophical theology (Vol. 2), Providence, scripture, and resurrection, Oxford University Press, Oxford

Rissler, J. 2010, 'Open theism', The Internet encyclopedia of philosophy, viewed 25 February 2010, from http://www.iep. utm.edu/

Stump, E., 1985, 'Modern biblical scholarship, philosophy of religion and traditional Christianity', Truth Journal, Volume 1, viewed 12 December 2009, from http://www.leaderu. com/truth/1truth20.html

Stump E. \& Flint, T.P., 1993, Hermes and Athena: Biblical exegesis and philosophical theology, Notre Dame University Press, Notre Dame.
Taylor, M.C., 1987, Erring: A post-modern a/theology, University of Chicago Press, Chicago.

Taylor, M.C., 2007, After God. Religion and postmodernism, University of Chicago Press, Chicago.

Trakakis, N., 2007, 'Meta-philosophy of religion: The analyticcontinental divide in philosophy of religion', Ars Disputandi 7, 1-47.

Vanhoozer, K., 1990, Biblical narrative in the philosophy of Paul Ricoeur: A study in theology and hermeneutics, Cambridge University Press, New York.

Ward, K., 1994, Religion and revelation: A Theology of revelation in the world's religions, Oxford University Press, Oxford.

Ward, K., 1996, Religion and creation, Oxford University Press, Oxford.

Ward, K., 1998a, Religion and human nature, Oxford University Press, Oxford.

Ward, K., 1998b, Concepts of God: Images of the Divine in five religious traditions, Oneworld Publications, Oxford.

Westphal, M., 1984, God, guilt, and death: An existential phenomenology of religion, Indiana University Press, Bloomington and Indianapolis.

Westphal, M., 1987, Studies in phenomenology and existential philosophy and Kierkegaard's critique of reason and society, Mercer University Press, Macon.

Wetzel, J., 2010, Journal of Philosophy and Scripture, viewed 10 March 2010, from http://www.philosophyandscripture. org/index.html 